\title{
The Effect of Academic Supervision in Improving Teacher Performance: A Literature Review
}

\author{
Sovian Hakim ${ }^{1}$, Sowiyah ${ }^{2}$, Zulaikha Fitriyanti ${ }^{3}$, Ryzal Perdana ${ }^{4}$, \\ \{ sovianhakim2@gmail.com ${ }^{1}$, sowi.unila@gmail.com², zulaikhafitriy@gmail.com³ \\ Ryzalperdana2009@gmail.com $\left.{ }^{4}\right\}$
}

\begin{abstract}
Master of Educational Administration University of Lampung Indonesia ${ }^{1}$, Faculty of Teacher Training and Education University of Lampung, Indonesia ${ }^{2}$, Master of Educational Administration University of Lampung Indonesia ${ }^{3}$, Faculty of Teacher Training and Education University of Lampung, Indonesia ${ }^{4}$
\end{abstract}

\begin{abstract}
Teachers play an important role in learning. As a professional teacher, supervision is needed to improve the implementation of the teaching process. The purpose of this literature review is to examine and Analyze the impact of academic supervision on improving teacher performance. The method in this study was carried out by reviewing related articles about academic supervision and teacher performance. The sample of this research is focused on the google schoolar search engine with academic coaching and teacher performance as the main research constraints and then identified. The results of the review articles, most of the role of academic supervision, are very influential in improving teacher performance even though there are still obstacles such as not yet participatory planning and implementation of academic supervision. Therefore, effective academic supervision requires the principal's willingness to plan, implement and evaluate participatory supervision.
\end{abstract}

Keywords: Academic supervision, teacher performance.

\section{Introduction}

Ability expressions that are based on knowledge, attitudes, skills, and motivation to produce something are defined as performance. Teacher performance is an achievement or performance carried out by teachers in carrying out their duties as educators, and the quality of educational outcomes is largely determined by the teacher, because the party who has the most direct contact with students in the learning process in school educational institutions and other educational institutions is the teacher. This is not only determined by one factor, but many things that have an influence in determining the improvement of the teacher's performance. Basically, the result of the result is performance, is the end point of people, bringing together certain resources and the environment, with the aim of appreciating certain things, such as the tangible product of less tangible service. To the extent that interactions produce the desired results and quality, at unreasonable cost levels performance is judged satisfactory, good, or excellent. Performance will be judged poor or difficult if the results are disappointing, for whatever reason.

In the learning process the teacher has a very important role. If the teacher works professionally is not impossible if a school can produce students who excel. Conversely, if human resources in this case the teachers in a school are not well managed, then the student output at the school will also be low [5]. This means that between human resources 
(teachers) and the quality of students in schools there is a positive correlation, where human resources need good management to reach quality students. In fact, one of the keys to the success of education quality in the country is teachers. Supervision and guidance are needed to improve the execution of the teaching process they do as professional teachers. A teacher who is considered capable of carrying out their duties with the conditions that they have fulfilled before they are appointed as teachers still needs supervision from various parties [3]. One of them is the principal who supervises. The duties and roles at school must be understood by a school principal. If the duties and roles of the principal can be understood by the principal, then it is easy for him to carry out all his duties, especially those related to the implementation of supervision.

Academic supervision is an activity in which teachers are assisted in developing the ability to manage learning so that effective and efficient learning objectives can be achieved [4]. It is hoped that teachers, as the pioneers of educational activities, will have a good performance in realizing high-quality character-based learning through supervision, so as to develop the potential of students into people who believe in and fear the almighty, noble, healthy, and knowledgeable God. Independent, capable, creative, and become a democratic and responsible citizen. Educational Supervision as an activity that is inseparable from the management activities of Education needs to be pursued simultaneously and improved the quality of its implementation. Education supervision has a strategic and important position in the management of education, it has become imperative for the government to strive continuously to make the implementers of education supervision a professional force [18].

Supervision has not been optimal. Supervision and observation objectives focus more on technical aspects and rarely involve administrative aspects directly related to the learning process [16]. Due to time constraints of supervisors, the principal supervisor did very little in frequency and intensity. Supervision of school principals in its implementation has not provided significant benefits for improving teacher professional skills. The principal should allow a larger portion of supervision to be directed at academic supervision to improve teacher professional abilities. A basic function (basic function) in the whole school plan is academic supervision, which shows that function is a source of information for teachers' professional development. The performer of academic supervision can be performed by the principal, to carry out management functions that aim to improve teacher professionalism.

Teacher performance can be seen through a performance appraisal which in principle is a way of measuring the contribution of individuals in the institution to the organization [30]. Academic supervision is one way of evaluating teacher performance through a systematic planning cycle, careful and careful observation. Through supervision it is expected that teachers will provide feedback with the improvement of the quality of performance. Academic supervision will have a positive impact on teachers professionally if it is carried out effectively [11]. The impact is visible from indicators such as: the invitation of teachers to be supervisors to supervise the class, increased teaching motivation, discussions between teachers began to take place, Improve teachers' innovative ability and creativity, and produce designs, artworks or intellectual property in the form of research, publications and students. which indicates an increasing trend achievement.

However, there are studies that draw conclusions about vocational high schools in Indonesia which show the results of the principal's academic supervision have a significant positive effect on the performance of teachers of the Private VHS Business Group and Management of Depok City, directly and indirectly through work motivation. This shows that improving teacher performance is not only improved work motivation. But the principal's academic supervision must also be improved [15]. 
Research has been carried out on principal leadership, academic supervision, and work motivation in improving teacher performance. The results obtained a significant positive correlation between academic supervision and teacher performance [10]. According to Ali Rifaldi in his research, the assessment of teacher performance in managing learning cannot be separated from academic supervision [8].

This makes it clear to us in understanding the influence system of academic supervision behavior. Directly, teacher behavior and teacher performance can be relied on by academic supervision. Through academic supervision, the teaching behavior of the supervisory teacher is better in the teaching process. Furthermore, good teacher teaching behavior will influence student behavior in learning. Writing this article aims to see the effect of supervision on teacher performance. Thus, the main research question for this research is "How should academic supervision be directed towards improving teacher performance?"

\section{Literature Review}

\subsection{Supervision}

Supervision is an effort given to teachers in performing professional tasks so that teachers can help students to learn better than before [32]. Supervision is an integral part of the functions of the school administrators [46],[38],[37]. Thus, supervision can also be interpreted as assistance in developing better learning or activities provided to help teachers carry out their work more optimally [41]. In this way, supervision has the function to direct, coordinate, develop, guide and regulate others in achieving the goals set in the school situation which leads to the understanding that supervision has a significant meaning to provide assistance and guidance [49].

Supervision is to improve classroom management strategies, adhering to curriculum content, shaping the direction and utilization of instructional activities and discipline for effective control measures [27],[28]. The aim of school supervision is to improve student learning but the direct focus is on teachers and the entire educational environment. [53],[25]. Supervision in education includes science, skills, personality, teacher welfare, staffing services, career paths, performance development, and professionalism, to bring teachers to an open, skillful attitude, their souls integrated with the task as an educator [22].

Effective supervision has characteriz, such as : (a). competency supervisor, (b). Academic supervision is planned to be prioritized in the supervision program, (c) more varied supervision techniques, (d) providing feedback according to teacher problems, (e) participatory supervision, (f) teacher support and commitment to self-improvement, ( $\mathrm{g}$ ) continuous coaching and mentoring, (h) increasing teacher competence in learning, (i) increasing student absorption and (j) continuous evaluation [16]. Supervision is an activity to help develop teacher skills and facilitate teachers in improving the learning process carried out by the principal [44]. Supervision is coaching that is planned in order to help teachers and other school staff do their work effectively [23].

From several meanings it can be understood that supervision is a series of efforts to compare the standards of a certain planned activity with implementation, as well as following up on these results. This means that supervision must be able to measure the results with the standard of certain activities. 


\subsection{Academic Supervision}

Academic supervision is an activity to help develop the ability of teachers to manage the learning process to achieve goals. Academic supervision is related to the assessment of teacher performance in managing subsequent learning [16], [34], [29]. Supervision is a way of cultivating teacher professionals to develop democratic leadership and solve the problem of the learning process effectively [17], [21], [36]. Effective learning supervision is carried out to achieve these goals, namely effective learning in order to improve the quality of education from efforts to increase the cognitive value of student learning achievement in subjects at the high school level, the principal previously conducted a problem analysis followed by problem identification and clarification [52].

Not only head master as supervisor, but it requires the responsibility of academic supervision of the vice principal. The responsibility of academic supervision of the vice principals is to focus on the process of supervising teachers in teaching, how the teaching media is, how learning is carried out and providing solutions to the problems faced [2], [43], [40]. In this process, how do teachers manage time, use teaching materials and practices that are expected to improve student academic achievement. This is because a significant factor affecting children's education is the quality of the teacher [48].

Academic supervision must change teachers to become competent, that is, teachers increasingly master their competences, both personal, pedagogical, professional, and social competences [26]. Through academic supervision, the teacher is assisted by the principal in managing the learning process, and the teacher is helped to develop his professionalism, in this case the teacher's performance in preparing learning tools [24]. Therefore academic supervision should address the development of all teacher competencies [51]. Students as mentors also play an important role in supervision. The relationship between academic instructors and supervisors is complex and affected by a variety of dynamic dynamics [9]. Therefore, it is useful to know whether students receiving academic guidance have opinions on their expectations of academic relationships and the support they receive from the mentor. In addition, determining how the students' views differ or converge with the supervisor's views are important topics to consider.

From the above theory, it can be concluded that a series of activities to assist teachers in developing their abilities in managing the learning process in a professional manner to achieve the expected learning objectives. There are four competencies that must be developed through academic supervision, namely personality, pedagogical, professional, and social competencies.

\subsection{Teacher Performance}

The result of work is performance and progress that has been achieved by someone in their field of work. Performance is synonymous with work performance or in English is called performance. Performance is always a sign of the success of an organization and the people who are in the organization. Performance is the key that must function effectively so that the organization as a whole can succeed. Performance is only a result of achieving measurable goals. But performance is how they achieve it, not just what is achieved. Good performance results are the result of appropriate behavior, especially wisdom in behavior, and effective behavior in accordance with the skills and competencies needed [6], [47]. Good and effective teacher performance will shape the school's work culture, thereby improving the quality of 
education and creating an effective school [42]. Furthermore Andriani, Kesumawati, and Kristiawan concluded that performance is the work of a person or organization by doing and producing Something, physical or non-physical according to instructions, functions and tasks based on knowledge, attitudes, skills, and motivation. Performance systems generally include behavior (what employees do) and results (results from employee behavior). The performance dimension does not include the results of the behavior, but the behavior itself [20], [35]. So performance is about behavior or what employees do, not what is produced or what results from their work. It describes two behavioral traits as evaluative and multimedia social performance.

Teacher performance is the result of teacher work in carrying out their duties based on abilities, skills, experience, abilities, according to their competence and job criteria [45]. The most common goal of classroom observation is teacher performance [39]. Lecturer or teacher performance is an important factor. The main assessor of teacher performance is students [5]. Teacher performance is the ability and success of the teacher to carry out learning. There is a significant effect of teacher performance on teacher teaching abilities [12], [31]. Teacher performance can be seen through several indicators 1) ability to compile lesson plans; 2) the ability to carry out learning; 3 ) the ability to do interpersonal relationships; 4) ability to assess learning outcomes; 5) ability to carry out enrichment programs; 6) ability to implement improvement programs [33].

Based on that teacher productivity in classes taught by performance teachers are more useful theoretical findings, because they come from any class too small to be of use. Efforts to improve teacher quality, whether through better recruitment and selection, increased in-service training, or efficient use of teachers all rely on the ability to check teacher performance on demand, quickly, economically, and accurately.

\section{Method}

This literature review focuses on the The influence of academic supervision on teacher performance. The review process begins with a search engine, google schooler, to search for articles with keywords. "The Effect of Academic Supervision in Improving Teacher Performance". The search was not limited and a total of studies and articles were identified. Thus, this literature review is built by gathering and filtering researches under these following conditions and search keys:

a. Supervision in Education :3.470.000 results

b. Academic Supervision: 198.000 results

c. Performance : 978.000 results

d. Teacher Performance : 379.000 results

e. Range of research year between 2014-2020

Thus, there are 23 papers found and suitable with this library research. The 23 papers are the most suitable because the papers are discussing about how the aspects of academic supervision can affect teachers' performance. The aspects are not only in the supervisor itself, but also in some other aspect like facilities and financial issues. 
Table 1. Academic supervision in improving teacher performance.

\begin{tabular}{|c|c|c|c|c|c|}
\hline $\begin{array}{c}\text { Author and } \\
\text { Year }\end{array}$ & Title & Country & Method & Sample & Resuslts \\
\hline $\begin{array}{l}\text { Andriani, } \\
\text { Kesumawati, } \\
\text { Kristiawan } \\
\text { (2018) }\end{array}$ & $\begin{array}{l}\text { The Influence Of } \\
\text { The } \\
\text { Transformational } \\
\text { Leadership And } \\
\text { Work Motivation On } \\
\text { Teachers } \\
\text { Performance }\end{array}$ & $\begin{array}{l}\text { Indonesi } \\
\mathrm{a}\end{array}$ & $\begin{array}{l}\text { Quantitati } \\
\text { ve }\end{array}$ & 193 teachers & $\begin{array}{l}\text { Transformational } \\
\text { leadership has a } \\
\text { significant effect on the } \\
\text { performance of SMK } \\
\text { teachers in Palembang. } \\
\text { This means that the } \\
\text { better the } \\
\text { transformational } \\
\text { leadership, the better the } \\
\text { performance school } \\
\text { vocational teachers in Palembang }\end{array}$ \\
\hline Arum (2017) & $\begin{array}{l}\text { The Development of } \\
\text { Elementary School } \\
\text { Headmaster's } \\
\text { Managerial } \\
\text { Performance } \\
\text { Assessment Model } \\
\text { Based } \\
\text { Competence } \\
\text { Standard }\end{array}$ & $\begin{array}{l}\text { Indonesi } \\
\mathrm{a}\end{array}$ & $\mathrm{RnD}$ & $\begin{array}{l}\text { Managerial } \\
\text { Performanc } \\
\mathrm{e} \\
\text { Assessment } \\
\text { Model }\end{array}$ & $\begin{array}{l}\text { Principal management } \\
\text { performance evaluation } \\
\text { model tools need to be } \\
\text { developed, so that the } \\
\text { evaluation of principals } \\
\text { can truly measure all } \\
\text { measurement aspects, } \\
\text { and the process of } \\
\text { processing the results is } \\
\text { very fast, so it is } \\
\text { necessary to improve the } \\
\text { principal management } \\
\text { performance evaluation } \\
\text { model }\end{array}$ \\
\hline $\begin{array}{l}\text { Ambarita, } \\
\text { Siburian, } \\
\text { Purba (2014) }\end{array}$ & $\begin{array}{l}\text { Development of } \\
\text { Academic } \\
\text { Supervision Model } \\
\text { which Based on } \\
\text { Educational } \\
\text { Management }\end{array}$ & $\begin{array}{l}\text { Indonesi } \\
\mathrm{a}\end{array}$ & $\mathrm{RnD}$ & $\begin{array}{l}30 \text { teachers } \\
\text { of } \\
\text { Indonesian }\end{array}$ & $\begin{array}{l}\text { The first stage of the art } \\
\text { model of academic } \\
\text { supervision has a good } \\
\text { performance value for } \\
\text { teachers. In cycle II, } \\
86.67 \% \text { of teachers had } \\
\text { good performance } \\
\text { scores, while } 13.33 \% \text { of } \\
\text { teachers had good } \\
\text { performance scores. }\end{array}$ \\
\hline $\begin{array}{l}\text { Ardiana } \\
\text { (2017) }\end{array}$ & 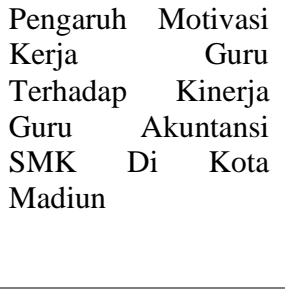 & $\begin{array}{l}\text { Indonesi } \\
\text { a }\end{array}$ & $\begin{array}{l}\text { Quantitati } \\
\text { ve }\end{array}$ & $\begin{array}{l}97 \\
\text { accounting } \\
\text { teachers }\end{array}$ & $\begin{array}{l}80.6 \% \text {, motivation has a } \\
\text { significant effect on } \\
\text { accounting teacher } \\
\text { performance and } 19.4 \% \\
\text { accounting teacher } \\
\text { performance r is } \\
\text { determined by factors } \\
\text { other than research. }\end{array}$ \\
\hline $\begin{array}{l}\text { Adewale } \\
\text { 2014) }\end{array}$ & $\begin{array}{l}\text { Instructional } \\
\text { Improvement of } \\
\text { Secondary School } \\
\text { Teachers through } \\
\text { Effective Academic }\end{array}$ & Nigeria & $\begin{array}{l}\text { Qualitativ } \\
\text { e }\end{array}$ & $\begin{array}{l}\text { Teachers' } \\
\text { improvemen } \\
\text { t level will } \\
\text { be evaluated } \\
\text { in mastery }\end{array}$ & $\begin{array}{lr}\text { Internal academic } \\
\text { supervision } \\
\text { undoubtedly the best } \\
\text { choice to improve } \\
\text { current quality and }\end{array}$ \\
\hline
\end{tabular}




\begin{tabular}{|c|c|c|c|c|c|}
\hline & $\begin{array}{l}\text { Supervision by the } \\
\text { Vice-Principals }\end{array}$ & & & $\begin{array}{l}\text { of subject } \\
\text { matter, } \\
\text { teaching } \\
\text { skills, and } \\
\text { use of } \\
\text { teaching } \\
\text { resources }\end{array}$ & $\begin{array}{l}\text { maintain a higher } \\
\text { standard, because it is } \\
\text { easy to obtain, supervise } \\
\text { with teachers, correct } \\
\text { and consolidate the } \\
\text { intimate relationship } \\
\text { between thought and } \\
\text { innovation. }\end{array}$ \\
\hline $\begin{array}{l}\text { Rifaldi \& } \\
\text { Roesminingsi } \\
\text { h (2014) }\end{array}$ & $\begin{array}{l}\text { Pengaruh Supervisi } \\
\text { Kepala Sekolah dan } \\
\text { Motivasi Kerja Guru } \\
\text { Terhadap Kepuasan } \\
\text { Kerja Guru di SMK } \\
\text { ADB INVEST Se- } \\
\text { Kota Surabaya }\end{array}$ & $\begin{array}{l}\text { Indonesi } \\
\text { a }\end{array}$ & $\begin{array}{l}\text { Quantitati } \\
\text { ve }\end{array}$ & 95 teachers & $\begin{array}{l}\text { There is an influence } \\
\text { significant from the } \\
\text { Principal's supervision } \\
\text { of teachers' job } \\
\text { satisfaction at SMK } \\
\text { ADB INVEST } \\
\text { throughout Surabaya } \\
\text { City } \\
\text { Significant influence of } \\
\text { work motivation } \\
\text { teacher to job } \\
\text { satisfaction of teachers } \\
\text { in vocational schools } \\
\text { ADB INVEST } \\
\text { throughout Surabaya } \\
\text { City; significant } \\
\text { Have a } \\
\text { impact } \\
\text { Supervision of School } \\
\text { Principals and Work } \\
\text { Motivation } \\
\text { Teacher together against } \\
\text { teacher job satisfaction } \\
\text { at ADB INVEST } \\
\text { Vocational School } \\
\text { Surabaya City }\end{array}$ \\
\hline Elliott (2015) & $\begin{array}{l}\text { Teacher } \\
\text { Performance } \\
\text { Appraisal: More } \\
\text { about Performance } \\
\text { or Development? }\end{array}$ & $\begin{array}{l}\text { Australi } \\
\text { a }\end{array}$ & $\begin{array}{l}\text { Qualitativ } \\
\text { e }\end{array}$ & $\begin{array}{l}\text { Teacher } \\
\text { performance } \\
\text { appraisal }\end{array}$ & $\begin{array}{l}\text { Evaluate the complexity } \\
\text { of performance } \\
\text { evaluation and its } \\
\text { impact on teacher } \\
\text { effectiveness, and } \\
\text { acknowledge the need } \\
\text { for further research in } \\
\text { this area. Keep in mind } \\
\text { that performance } \\
\text { evaluation, teacher } \\
\text { standards and } \\
\text { professional learning are } \\
\text { difficult to separate. }\end{array}$ \\
\hline $\begin{array}{l}\text { Hardono, } \\
\text { Haryono, } \\
\text { Yusuf (2017) }\end{array}$ & \begin{tabular}{lr}
\multicolumn{2}{l}{ Kepemimpinan } \\
Kepala & Sekolah, \\
Supervisi & \\
Akademik, & dan \\
$\begin{array}{l}\text { Motivasi } \\
\text { dalam }\end{array}$ & Kerja \\
\end{tabular} & $\begin{array}{l}\text { Indonesi } \\
\text { a }\end{array}$ & $\begin{array}{l}\text { Quantitati } \\
\text { ve }\end{array}$ & 123 teachers & $\begin{array}{l}\text { Principal leadership and } \\
\text { Academic supervision } \\
\text { has an effect on good } \\
\text { work motivation } \\
\text { partially or } \\
\text { simultaneously }\end{array}$ \\
\hline
\end{tabular}




\begin{tabular}{|c|c|c|c|c|c|}
\hline & $\begin{array}{l}\text { Meningkatkan } \\
\text { Kinerja Guru }\end{array}$ & & & & \\
\hline Astuti (2017) & $\begin{array}{l}\text { Supervisi Akademik } \\
\text { Untuk Menigkatkan } \\
\text { Kompetensi Guru di } \\
\text { SD Laboratorium } \\
\text { UKSW }\end{array}$ & $\begin{array}{l}\text { Indonesi } \\
\mathrm{a}\end{array}$ & $\begin{array}{l}\text { School } \\
\text { Action } \\
\text { Research }\end{array}$ & 15 teachers & $\begin{array}{l}\text { Academic supervision } \\
\text { can improve the ability } \\
\text { of teachers in particular } \\
\text { ability to arrange } \\
\text { appraisal administration. } \\
\text { In order to improve } \\
\text { teacher's ability is } \\
\text { needed guidance and } \\
\text { direction from the } \\
\text { principal as a teacher } \\
\text { supervisor. }\end{array}$ \\
\hline $\begin{array}{l}\text { Dee } \quad \& \\
\text { Wyckoff } \\
(2015)\end{array}$ & $\begin{array}{ll}\text { Incentives, } & \\
\text { Selection, } & \text { and } \\
\text { Teacher } & \\
\text { Performance: } & \\
\text { Evidence } & \\
\text { IMPACT } & \end{array}$ & $\begin{array}{l}\text { United } \\
\text { States }\end{array}$ & $\begin{array}{l}\text { Descriptiv } \\
\text { e } \\
\text { Quantitati } \\
\text { ve }\end{array}$ & $\begin{array}{l}\text { Approximat } \\
\text { ely 2,630 } \\
\text { teachers }\end{array}$ & $\begin{array}{l}\text { There is a relatively } \\
\text { strong consensus } \\
\text { regarding the following } \\
\text { points of view: teachers } \\
\text { will have a significant } \\
\text { and long-term impact on } \\
\text { students educational } \\
\text { and economic results, } \\
\text { and under the current } \\
\text { basically static teacher } \\
\text { evaluation and } \\
\text { compensation system, } \\
\text { the quality of teachers is } \\
\text { very different. }\end{array}$ \\
\hline $\begin{array}{l}\text { Naggar, } \\
\text { Sarory, } \\
\text { Naggar, Al- } \\
\text { Muosli }\end{array}$ & $\begin{array}{l}\text { Doctorate } \\
\text { international } \\
\text { students' } \\
\text { satisfaction and } \\
\text { stress on academic } \\
\text { supervision in a } \\
\text { Malaysian } \\
\text { University: a } \\
\text { qualitative approach }\end{array}$ & $\begin{array}{l}\text { Malaysi } \\
\text { a }\end{array}$ & $\begin{array}{l}\text { Qualitativ } \\
\mathrm{e}\end{array}$ & $\begin{array}{l}9 \quad \mathrm{PhD} \\
\text { students }\end{array}$ & $\begin{array}{l}\text { Most international } \mathrm{PhD} \\
\text { students mentioned that } \\
\text { the supervision system } \\
\text { makes them feel worried } \\
\text { and stressed. }\end{array}$ \\
\hline $\begin{array}{lr}\text { Gatrix } \quad \& \\
\text { Barrett }(2016)\end{array}$ & $\begin{array}{l}\text { Desperately seeking } \\
\text { consistency: Student } \\
\text { nurses' experiences } \\
\text { and expectations of } \\
\text { academic } \\
\text { supervision }\end{array}$ & $\begin{array}{l}\text { United } \\
\text { Kingdo } \\
\mathrm{m}\end{array}$ & $\begin{array}{l}\text { Qualitativ } \\
\mathrm{e}\end{array}$ & 8 students & $\begin{array}{l}\text { It is important that } \\
\text { students do not be afraid } \\
\text { to contact their } \\
\text { superiors, because if the } \\
\text { relationship between } \\
\text { superiors and students is } \\
\text { more positive, they are } \\
\text { more likely to put more } \\
\text { energy into their work } \\
\text { and get support again in } \\
\text { future modules }\end{array}$ \\
\hline $\begin{array}{l}\text { Guarino, } \\
\text { Maxfield, } \\
\text { Reckase, } \\
\text { Thompson, } \\
\text { Wooldridge } \\
\text { (2015) }\end{array}$ & $\begin{array}{l}\text { An Evaluation of } \\
\text { Empirical Bayes's } \\
\text { Estimation of Value- } \\
\text { Added Teacher } \\
\text { Performance } \\
\text { Measures }\end{array}$ & $\begin{array}{l}\text { United } \\
\text { States }\end{array}$ & $\begin{array}{l}\text { Quantitati } \\
\text { ve }\end{array}$ & $\begin{array}{l}\text { Empirical } \\
\text { Bayes's } \\
\text { Estimation }\end{array}$ & $\begin{array}{l}\text { If the allocation } \\
\text { mechanism is known to } \\
\text { be random, it may be } \\
\text { appropriate to apply } \\
\text { these AR and EB } \\
\text { estimates, especially }\end{array}$ \\
\hline
\end{tabular}




\begin{tabular}{|c|c|c|c|c|c|}
\hline & & & & & $\begin{array}{l}\text { when the amount of data } \\
\text { per teacher is minimal. }\end{array}$ \\
\hline $\begin{array}{l}\text { Suarda, } \\
\text { Yadnyawati, } \\
\text { Suda (2018) }\end{array}$ & $\begin{array}{l}\text { Portrait of Hindu } \\
\text { Religious Teacher } \\
\text { Performance } \\
\text { Certified Educator in } \\
\text { Junior High Schools } \\
\text { Denpasar }\end{array}$ & $\begin{array}{l}\text { Indonesi } \\
\text { a }\end{array}$ & $\begin{array}{l}\text { Qualitativ } \\
\text { e }\end{array}$ & $\begin{array}{l}\text { Hindu } \\
\text { Religious } \\
\text { Teacher's } \\
\text { performance }\end{array}$ & $\begin{array}{l}\text { The performance of } \\
\text { Hindu religious teachers } \\
\text { who have pocketed an } \\
\text { educator certificate at } \\
\text { SMP Denpasar is not yet } \\
\text { good. This is due to } \\
\text { several heasons, } \\
\text { including human } \\
\text { resources, } \\
\text { infrastructure, } \\
\text { leadership systems and } \\
\text { supervisory systems }\end{array}$ \\
\hline $\begin{array}{l}\text { Rahabav } \\
\text { (2016) }\end{array}$ & $\begin{array}{l}\text { The Effectiveness of } \\
\text { Academic } \\
\text { Supervision for } \\
\text { Teachers }\end{array}$ & $\begin{array}{l}\text { Indonesi } \\
\mathrm{a}\end{array}$ & $\begin{array}{l}\text { Qualitativ } \\
\mathrm{e}\end{array}$ & $\begin{array}{l}\text { 1 } \text { Principal } \\
9 \text { Regular } \\
\text { teachers }\end{array}$ & $\begin{array}{l}\text { The academic } \\
\text { supervision performed } \\
\text { by the principal is } \\
\text { invalid for the following } \\
\text { reasons. First of all, } \\
\text { from the supervisor; 1) } \\
\text { Time constraints (many } \\
\text { management tasks must } \\
\text { be completed); 2) } \\
\text { Participatory } \\
\text { programming has not } \\
\text { yet been carried out; (3) } \\
\text { Insufficient } \\
\text { understanding of the } \\
\text { supervisor's concept of } \\
\text { supervision, theory and } \\
\text { practice; 4) Every } \\
\text { teacher will teach Lack } \\
\text { of understanding of } \\
\text { scientific supervisors } \\
\text { related to the research } \\
\text { field }\end{array}$ \\
\hline $\begin{array}{l}\text { Waang, } \\
\text { Matin, Ahmad } \\
\text { (2019) }\end{array}$ & \begin{tabular}{lr}
\multicolumn{2}{l}{ Pengaruh Efektivitas } \\
Manajerial Kepala \\
Sekolah dan Etos \\
Kerja & Terhadap \\
Kinerja & Guru \\
Sekolah Dasar di \\
Kecamatan Teluk \\
Mutiara & Kabupaten \\
Alor
\end{tabular} & $\begin{array}{l}\text { Indonesi } \\
\mathrm{a}\end{array}$ & $\begin{array}{l}\text { Quantitati } \\
\text { ve }\end{array}$ & 146 teachers & $\begin{array}{l}\text { Effectiveness } \\
\text { managerial of } \\
\text { headmasters directly } \\
\text { positive for teacher } \\
\text { performance. Which } \\
\text { means the better the } \\
\text { level of managerial } \\
\text { effectiveness of the } \\
\text { principal, } \\
\text { performance } \\
\text { elementary } \\
\text { teachers in Theluk } \\
\text { Mutiara Subdistrict, } \\
\text { Alor Regency is getting } \\
\text { better. }\end{array}$ \\
\hline $\begin{array}{l}\text { Mackinnon } \\
\text { (2004) }\end{array}$ & $\begin{array}{l}\text { Academic } \\
\text { Supervision: seeking }\end{array}$ & $\begin{array}{l}\text { New } \\
\text { Zealand }\end{array}$ & $\begin{array}{l}\text { Qualitativ } \\
\text { e }\end{array}$ & $\begin{array}{l}\text { Metaphors } \\
\text { and models }\end{array}$ & $\begin{array}{l}\text { These conclusions about } \\
\text { best practices are partial }\end{array}$ \\
\hline
\end{tabular}




\begin{tabular}{|c|c|c|c|c|c|}
\hline & $\begin{array}{l}\text { metaphors and } \\
\text { models for quality }\end{array}$ & & & $\begin{array}{l}\text { for quality in } \\
\text { Academic } \\
\text { Supervision }\end{array}$ & $\begin{array}{l}\text { because they are proven } \\
\text { correct by past } \\
\text { experience, } \\
\text { experience, and other } \\
\text { experiences. More } \\
\text { resources are needed to } \\
\text { help supervisors provide } \\
\text { high-quality quality } \\
\text { supervision in complex } \\
\text { relationships that are } \\
\text { difficult to predict future } \\
\text { problems }\end{array}$ \\
\hline $\begin{array}{l}\text { Khoeriyah } \\
\text { (2015) }\end{array}$ & $\begin{array}{l}\text { Effect On } \\
\text { Performance } \\
\text { Supervision } \\
\text { Academic Teacher } \\
\text { In SMP IT Yaspida } \\
\text { Sukabumi }\end{array}$ & $\begin{array}{l}\text { Indonesi } \\
\text { a }\end{array}$ & $\begin{array}{l}\text { Descriptiv } \\
\text { e } \\
\text { Quantitati } \\
\text { ve }\end{array}$ & 3 teachers & $\begin{array}{l}\text { Principal's academic } \\
\text { supervision } \\
\text { performance } \\
\text { YASPIDA IT Middle } \\
\text { School tof } \\
\text { Sukabumi is quite good } \\
\text { with results by doing f } \\
\text { test and t-test }\end{array}$ \\
\hline $\begin{array}{l}\text { Medley \& } \\
\text { Coker (2015) }\end{array}$ & $\begin{array}{ll}\text { The Accuracy } & \text { of } \\
\text { Principals' } & \\
\text { Judgments } & \text { of } \\
\text { Teacher } & \\
\text { Performance } & \end{array}$ & $\begin{array}{l}\text { United } \\
\text { States }\end{array}$ & $\begin{array}{l}\text { Quantitati } \\
\text { ve }\end{array}$ & 322 teachers & $\begin{array}{l}\text { The principal's average } \\
\text { judgment on the } \\
\text { performance of the } \\
\text { teachers he or she } \\
\text { supervises is still not } \\
\text { accurate enough }\end{array}$ \\
\hline $\begin{array}{l}\text { Prasetyono, } \\
\text { Abdillah, } \\
\text { Fitria (2018) }\end{array}$ & $\begin{array}{l}\text { Academic } \\
\text { Supervision toward } \\
\text { Teacher's } \\
\text { Performance } \\
\text { through Motivation } \\
\text { as Intervening } \\
\text { Variable }\end{array}$ & $\begin{array}{l}\text { Indonesi } \\
\mathrm{a}\end{array}$ & $\begin{array}{l}\text { Quantitati } \\
\text { ve }\end{array}$ & 80 teachers & $\begin{array}{l}\begin{array}{l}\text { Directly and indirectly } \\
\text { through } \\
\text { motivation, } \\
\text { the }\end{array} \\
\text { principal's academic } \\
\text { supervision has a } \\
\text { significant positive } \\
\text { effect on the } \\
\text { performance of the } \\
\text { Business Group and } \\
\text { Management of VHS } \\
\text { Public Private Group } \\
\text { teachers in Depok City. }\end{array}$ \\
\hline $\begin{array}{l}\text { Podgursky \& } \\
\text { Springer } \\
(2007)\end{array}$ & $\begin{array}{l}\text { Teacher } \\
\text { Performance Pay: A } \\
\text { Review }\end{array}$ & $\begin{array}{l}\text { United } \\
\text { States }\end{array}$ & $\begin{array}{l}\text { Descriptiv } \\
\text { e } \\
\text { Quantitati } \\
\text { ve }\end{array}$ & $\begin{array}{l}\text { Teachers' } \\
\text { payment }\end{array}$ & $\begin{array}{l}\text { Education policy makers } \\
\text { need to be careful when } \\
\text { designing such plans } \\
\text { and must expect to } \\
\text { continuously improve } \\
\text { these plans while } \\
\text { understanding } \\
\text { behavioral responses }\end{array}$ \\
\hline $\begin{array}{l}\text { Muralidharan } \\
\& \\
\text { Sundararaman } \\
(2009)\end{array}$ & $\begin{array}{l}\text { Teacher } \\
\text { Performance Pay: } \\
\text { Experimental } \\
\text { Evidence From India }\end{array}$ & India & $\begin{array}{l}\text { Quantitati } \\
\text { ve }\end{array}$ & 300 schools & $\begin{array}{l}\text { Teacher's performance } \\
\text { pay is an idea with } \\
\text { strong supporters and } \\
\text { opponents. So far, the } \\
\text { empirical evidence on } \\
\text { its performance is } \\
\text { uneven }\end{array}$ \\
\hline
\end{tabular}




\begin{tabular}{|c|c|c|c|c|c|}
\hline $\begin{array}{l}\text { Hansen, } \\
\text { Thomsen, } \\
\text { Nordentoft } \\
\text { (2014) }\end{array}$ & $\begin{array}{l}\text { Challenges in } \\
\text { Collective } \\
\text { Academic } \\
\text { Supervision: } \\
\text { supervisors' } \\
\text { experiences from a } \\
\text { Master Programme } \\
\text { in Guidance and } \\
\text { Counsellin }\end{array}$ & $\begin{array}{l}\text { Denmar } \\
\mathrm{k}\end{array}$ & $\begin{array}{l}\text { Qualitativ } \\
\mathrm{e}\end{array}$ & $\begin{array}{l}5 \\
\text { supervisors } \\
19 \text { students }\end{array}$ & $\begin{array}{l}\text { The monitoring methods } \\
\text { used, the expectations } \\
\text { and experiences of the } \\
\text { supervisors all have an } \\
\text { impact on the students' } \\
\text { behavior }\end{array}$ \\
\hline
\end{tabular}

\section{Result and discussion}

Based on the results of literature reviews and the comments obtained from the comments obtained, the analysis shows that most articles focus on the impact of academic supervision on improving teacher performance. It can be seen from the review articles that most academic supervision has a great influence on improving teacher performance.

There are many factors that hinder the effectiveness of academic supervision of the principal, including: first, the supervisor: 1) must complete a lot of administrative work; 2) not planning and implementing academic supervision in a participatory manner; 3) the concept, theory and practice of supervision by supervisors Lack of understanding; 4) Lack of understanding of the essence of scientific principles related to the research field taught by each teacher. 2. Teachers: 1) Low commitment to quality; 2) Motivation of teachers to specialize in pursuing prosperity. Based on this, to facilitate academic supervision, what is needed is the principal's plan, the willingness to carry out and evaluate participatory academic supervision. [16].

Whereas, not only the supervisor him or herself become the main issue that affects teachers' performance. Teacher's performance pay is an idea with strong supporters and opponents. So far, the empirical evidence on its performance is uneven [13]. That means, financial issues and facilities are also taking an important role in affecting teachers' performance. Education policy makers need to be cautious when designing such procedures and must expect them to continuously improve the procedures as they understand behavioral responses. The programs mentioned above are closely related to financial topics which are becoming one of issues that affect teachers' performance [14].

\section{Conclusion}

Based on the analysis of the above papers and research. It can be concluded that academic supervision is obviously an important aspect of improving teacher performance. The effectiveness of managerial affect headmasters directly positive for teacher performance [20]. Which means the better the level of managerial effectiveness of the principal, the better the performance of Elementary school teachers in Teluk Mutiara District, Alor Regency. Academic supervision can improve teachers' abilities in particular ability to arrange appraisal 
administration. In order to improve teacher's ability is needed guidance and direction from the principal as a teacher supervisor [7]. Although other factor like financial issue is still another problem due to education world has become such a beneficial business.

Acknowledgments. The biggest award is given to people who have helped, supported and provide motivation and guidance in completing the article. Thank you to Mr. Hasan Hariri who has been patient and never tired to spend his energy and time to provide full support and participation in this research and Mrs. Sowiyah as an academic guide who is willing to take the time and provide support amid her busy schedule and still participate in this research.

\section{References}

[1] Ambiyar, Ambiyar, Asmar Yulastri, Mimi Yupelmi, And Paryono, P. Relevance of The Production Course of Hair Beauty in Vocational High Schools to Industry Needs. Jurnal Pendidikan Teknologi dan Kejuruan. 2018; 24(1):125-131. https://doi.org/10.21831/Jptk.V24i1.18388.

[2] Adewale, Orenaiya Solomon. Instructional Improvement Of Secondary School Teachers Through Effective Academic Supervision By The Vice-Principals. Journal Of Education And Human Development. 2018; 3(2):607-617.

[3] Amanda, Mentari Ocvilia, Salam Rudi And Saggaf Said. Pengaruh Supervisi Kepala Sekolah Terhadap Kinerja Guru Di Smk Negeri 1 Bungoro Kabupaten Pangkep. Prosiding Seminar Nasional Himpunan Sarjana Ilmu-Ilmu Sosial. 2017. P. 149-154.

[4] Ambarita Biner, Siburian Paningkat, And Purba Sukarman. Development of Academic Supervision Model Which Based On Educational Management. International Journal Of Sciences: Basic And $\begin{array}{llll}\text { Applied } & \text { Research } & \text { (Ijsbar). } & \text { 2014; }\end{array}$ Http://Gssrr.Org/Index.Php?Journal=Journalofbasicandapplied

[5] Ardiana, Titin Eka. Pengaruh Motivasi Kerja Guru Terhadap Kinerja Guru Akuntansi Smk Di Kota Madiun. Jurnal Akuntansi Dan Pajak. 2017; 17(2). Https://Doi.Org/10.29040/Jap.V17i02.11.

[6] Arum, Wahyu Sri Ambar. The Development of Elementary School Headmaster's Managerial Performance-Assessment Model Based On Competence Standard. 9th International Conference For Science Educators And Teachers (Icset 2017) : Atlantis Press; 2017. Https://Doi.Org/10.2991/Icset17.2017.127

[7] Astuti, Suhandi. Supervisi Akademik Untuk Meningkatkan Kompetensi Guru Di Sd Laboratorium Uksw. Scholaria: Jurnal Pendidikan Dan Kebudayaan. 2017; 7(2):49-59. Https://Doi.Org/10.24246/J.Scholaria.2017.V7.I1.P49-59

[8] Gordon Stephen P, Ross Gordon Jovita M. Supervision And Instructional Leadership: A Developmental Approach: Pearson Allyn \& Bacon; 2007.

[9] Gratrix Lesley, Barrett David. Desperately Seeking Consistency: Student Nurses' Experiences And Expectations Of Academic Supervision. Nurse Education Today. 2017; 48:7-12. Https://Doi.Org/10.1016/J.Nedt.2016.09.005

[10] Hardono Hardono, Haryono Haryono, Yusuf Amin. Kepemimpinan Kepala Sekolah, Supervisi Akademik, Dan Motivasi Kerja Dalam Meningkatkan Kinerja Guru. Educational Management. 2017; 6(1):26-33.

[11] Khoeriyah Siti Wardiatul. Pengaruh Supervisi Akademik Terhadap Kinerja Guru Smp It Yaspida Sukabumi. Tadbir Muwahhid. 2017; 4(2). Https://Doi.Org/10.30997/Jtm.V4i2.344.

[12] Medley Donald M, Coker Homer. The Accuracy Of Principals' Judgments Of Teacher Performance. The Journal Of Educational Research. 2015; 80(4):242-247. Https://Doi.Org/10.1080/00220671.1987.10885759

[13] Muralidharan Karthik, Sundararaman Venkatesh. Teacher Performance Pay: Experimental Evidence From India. Journal Of Political Economy. 2011; 119(1):39-77.

[14] Podgursky Michael J, Springer Matthew G. Teacher Performance Pay: A Review. Journal Of Policy Analysis And Management: The Journal Of The Association For Public Policy Analysis And Management. 2007; 26(4). Https://Doi.Org/10.1002/Pam.20292. 
[15] Prasetyono Hendro, Abdillah Agus And Fitria Dona. Academic Supervision Toward Teacher's Performance Through Motivation As Intervening Variable. Journal Of Education And Learning (Edulearn). 2018; 12(2):188-197. Https://Doi.Org/10.11591/Edulearn.V12i2.7324.

[16] Rahabav Patris. The Effectiveness Of Academic Supervision For Teachers. Journal Of Education And Practice. 2016; 7(9):47-55. Www.Iiste.Org

[17] Sagala Syaiful. Supervisi Pembelajaran Dalam Profesi Pendidikan. Bandung: Alfabeta; 2017.

[18] Sudin Ali. Implementasi Supervisi Akademik Terhadap Proses Pembelajaran Di Sekolah Dasar Se Kabupaten Sumedang. Jurnal Pendidikan Dasar; 2008.

[19] Syaiful Sagala. Manajemen Berbasis Sekolah Dan Masyarakat. Jakart: Pt Rakasta Samasta; 2006.

[20] Waang, Magdalena, Ahmad Masduki. Pengaruh Efektivitas Manajerial Kepala Sekolah Dan Etos Kerja Terhadap Kinerja Guru Sekolah Dasar Di Kecamatan Teluk Mutiara Kabupaten Alor. Jurnal Ilmiah Wahana Pendidikan. 2019; 5(1):98105.Http://Jurnal.Unibrah.Ac.Id/Index.Php/Jiwp/Article/View/78/62.

[21] Abreu, A., Cardoso, A. P., \& Rocha, J. Teachers' Perception of The Head of Department's Performance and of Pedagogical Supervision. Millenium-Journal of Education, Technologies, and Health. 2019; 2:47-59. doi:10.29352/mill0203e.04.00206.

[22] Aripin, A., Arafat, Y., \& Fitria, H. The Effect of Certification and Principal's Supervision Toward Teacher's Performance. International Journal of Progressive Sciences and Technologies. 2020; 20(2):19-27. Retrieved from http://ijpsat.ijsht-journals.org.

[23] Atieno, O. E., Jotham, O., \& Onyango, A. G. Perceptions of Principals, Heads of Departments and Teachers Regarding Effectiveness of Principals'instructional Supervision in Assisting Teachers in The Implementation of The Curriculum. European Journal of Education Studies. 2018; 5(7):172187. doi:10.5281/zenodo.2218577.

[24] Azwardi, A. Efforts to Improve Teacher Competency in Developing Learning Materials Through Collaborative Academic Supervision. Indonesian Educational Administration and Leadership Journal. 2020; 2(1):1-14. Retrieved from https://online-journal.unja.ac.id/index.php/IDEAL.

[25] Carlos, A. P., Cardoso, S., Galante, S., Lamy, F., Silva, P., Gaspar, I., \& Seabra, F. Supervision in Continuous Teacher Training. Enseñanza and Teaching:: Revista Interuniversitaria de Didáctica. 2017; 35:185-206. doi:10.14201/et2017351185206.

[26] Comfort, A., Aina, B. C., \& Idowu, A. F. Academic Supervision as A Correlate of Students' Academic Performance in Secondary Schools in Ekiti State, Nigeria. International Journal of Educational Policy Research and Review. 2017; 4(1):8-13. doi:10.15739/IJEPRR.17.002.

[27] Edo, B. L., \& David, A. A. Influence of School Supervision Strategies on Teachers' Job Performance in Senior Secondary Schools in Rivers State. International Journal of Innovative Development and Policy Studies. 2019; 7(4):45-54. Retrieved from www.seahipaj.org.

[28] Egwu, S. O. Principals' Performance in Supervision of Classroom Instruction in Ebonyi State Secondary Schools. Journal of Education and Practice. 2015; 6(15):99-105. Retrieved from www.iiste.org.

[29] Fahmi, C. N., Murniati, A., Nurliza, E., \& Usman, N. The Implementation of Academic Supervision in Improving Teacher Competency at Primary School. Jurnal Ilmiah Peuradeun. 2019; 7(1):181-194. doi:10.26811/peuradeun.v7i1.202.

[30] Hoojqan, A. R., Gharamani, J., \& Safari, S. A. The Effect of Educational Supervision on Improving Teachers' Performances in Guidance Schools of Marand. Indian Journal of Fundamental and Applied Life Sciences. 2015; 5(S2):1731-1735. Retrieved from www.cibtech.org/sp.ed/jls/2015/02/jls.htm.

[31] Hoque, K. E., Bt Kenayathulla, H. B., D/O Subramaniam, M. V., \& Islam, R. Relationships Between Supervision and Teachers' Performance and Attitude in Secondary Schools in Malaysia. SAGE Open. 2020; 10(2):2158244020925501. doi:10.1177/2158244020925501.

[32] Irungu, C., Kagema, J., \& Gachahi, M. Principals' supervision of teaching and its influence on promoting learners' performance. Journal of Pedagogical Sociology and Psychology. 2019; 1(1):3344. Retrieved from ww.j-psp.com.

[33] Kartini, D., Kristiawan, M., \& Fitria, H. The Influence of Principal's Leadership, Academic Supervision, and Professional Competence toward Teachers' Performance. International Journal of 
Progressive Sciences and Technologies.. 2019; 2(1):156-164. Retrieved from http://ijpsat.ijshtjournals.org.

[34] Kholid, K., \& Madjdi, A. H. Analysis of Principal's Academic Supervision and Teacher's Work Motivation Toward The Performance of State Elementary School Teachers in Undaan District Kudus Regency. Refleksi Edukatika: Jurnal Ilmiah Kependidikan, 2020; 10(2):257-266. Retrieved from http://jurnal.umk.ac.id/index.php/RE.

[35] Komariah, A., Sunaengsih, C., Kurniadi, D., Soemarto, S., \& Nurlatifah, S. How Professional Learning Community Based Academic Supervision Model Improves Teachers' Performance. Paper presented at the 2nd International Conference on Research of Educational Administration and Management (ICREAM 2018); 2018.

[36] Latiana, L., Samsudi, S., Pranoto, S., \& Slameto, S. Academic Supervision Model for The Early Childhood Education in The Municipality of Semarang. The Journal of Educational Development. 2017; 5(3):434-444. doi:10.15294/jed.v5i3.18132.

[37] Mardiyah, S. The Effectiveness of Supervision on Islamic Education (PAI) Teacher's Performance of Junior High School (SMP) in Pangkalpinang. Berumpun: International Journal of Social, Politics, and Humanities. 2019; 2(1):40-50.

[38] Mette, I. M., Range, B. G., Anderson, J., Hvidston, D. J., \& Nieuwenhuizen, L. Teachers' Perceptions of Teacher Supervision and Evaluation: A Reflection of School Improvement Practices in the Age of Reform. Education Leadership Review. 2016; 16(1):16-30.

[39] Moradi, K., Sepehrifar, S., \& Khadiv, T. P. Exploring Iranian EFL Teachers' Perceptions on Supervision. Procedia-Social and Behavioral Sciences. 2014; 98:1214-1223. doi:10.1016/j.sbspro.2014.03.536.

[40] Mujiati, M., Suriansyah, A., \& Effendi, R. Effect of Academic Supervision and School Culture on Teacher's Teaching Quality in Public Islamic Senior High School Banjarmasin. Journal of K6, Education and Management. 2019; 2(2):126-132.

[41] Murtiningsih, M., Kristiawan, M., \& Lian, B. The Correlation Between Supervision of Headmaster and Interpersonal Communication With Work Ethos of the Teacher. European Journal of Education Studies. 2019; 6(1):246-256. doi:10.5281/zenodo.2649535.

[42] Mutohar, P. M., \& Trisnantari, H. E. The Effectiveness of Madrasah: Analysis of Managerial Skills, Learning Supervision, School Culture, and Teachers' Performance. MOJEM: Malaysian Online Journal of Educational Management. 2020; 8(3):21-47. Retrieved from http://mojem.um.edu.my.

[43] Noor, I. H., \& Sofyaningrum, E. The Academic Supervision of The School Principal: A Case in Indonesia. Journal of Educational and Social Research. 2020; 10(4):81-81. doi:10.36941/jesr-20200067

[44] Nurhayati, T., Masnun, M., Udin, T., \& Arifuddin, A. Implementation of Principal Supervision as An Effort to Fulfill Teacher Administration at Islami Celementary School. Universal Journal of Educational Research. 2019; 7(8):1826-1831. doi:10.13189/ujer.2019.0 7082.

[45] Nurkolis, N., Warastuty, R., \& Yuliejantiningsih, Y. Do Academic Supervision and Activities in MGMP (Subject Teacher Deliberations) Increase Teachers Performance? Paper presented at the 3rd International Conference on Research of Educational Administration and Management (ICREAM 2019); 2020.

[46] Okonkwo, C. C., \& Okafor, P. S. Influence of Supervision of Instruction on Teachers' Classroom Performance in Anambra State. Multidisciplinary Journal of Education, Research and Development. 2019; 3(1):51-70.

[47] Pratami, F. A. R., Harapan, E., \& Arafat, Y. Influence of School Principal and Organizational Climate Supervision on Teachers' Performance. INTERNATIONAL JOURNAL OF SCIENTIFIC \& TECHNOLOGY RESEARCH. 2018; 7(7):228-236. Retrieved from www.ijstr.org.

[48] Roti, R. S., Lumapow, H. R., \& Sumual, S. D. Implementation Academic Supervision of Principals at Taraitak Public Elementary School Langowan District, Indonesia. IJAR. 2020; 6(7):106-111. Retrieved from www.allresearchjournal.com.

[49] Saihu, S. The Urgency of Total Quality Management in Academic Supervision to Improve The Competency of Teachers. Edukasi Islami: Jurnal Pendidikan Islam. 2020; 9(02):297-323. doi:10.30868/ei.v9i02.905. 
[50] Sartana, S. Improving School Principal Competence in Implementing Academic Supervision Through Monitoring and Evaluation Methods in Indragiri Hulu Regency. JURNAL PAJAR (Pendidikan dan Pengajaran). 2020; 4(2):347-355. doi:10.33578/pjr.v4i2.7966.

[51] Susanti, S., Wardiah, D., \& Lian, B. Effect of Academic Supervision of School Heads and School Culture on Quality Teaching Teachers. International Journal of Progressive Sciences and Technologies. 2020; 20(1):67-77. Retrieved from http://ijpsat.ijsht-journals.org.

[52] Ujiarto, T., Rusdarti, R., Rifai, R., \& Raharjo, T. J. Effect of The School Principal's Management, Academic Supervision, Organizational Culture, and Work Motivation to The Teacher's Professionalism. The Journal of Educational Development. 2017; 5(3):414-424. doi:10.15294/jed.v5i3.18128

[53] Wairimu, M. J. Teachers' Perception on Classroom Observation and Checking of Pupils' Exercise Books by Head Teachers on Performance of Duty in Primary Schools in Nakuru North District, Kenya. Journal of Education \& Socila Policy. 2016; 3(3):80-87. Retrieved from www.jespnet.com. 